\title{
APROPRIAÇÕES NOS TERRITÓRIOS CURRICULARES: Cartografando de-formações na história da arte
}

\author{
Carin Cristina Dahmer \\ Marilda Oliveira de Oliveira ${ }^{(*)}$
}

\section{NOS ENTRE-TEMPOS DA HISTÓRIA DA ARTE}

Para realizar esta pesquisa em educação e seus desdobramentos com as artes visuais, me coloquei em composição entre os encontros que tive, tanto nos espaços educativos, como nos espaços formativos da pós-graduação. Essas docências se construíram pelo viés da multiplicidade, pelos percursos que experienciei do currículo que busquei desorganizar a partir da história da arte, também múltipla em suas perspectivas e possibilidades. Experienciar a docência em diferentes espaços formativos, contribuiu para compor com o espaço da escola, para abordar o currículo em artes, e propor outras produções de sentidos com as imagens do passado. Parti de alguns anseios para tramar com a educação das artes visuais possíveis relações entre a história e a arte.

Percebo a história a partir de suas potencialidades para pensar o presente, deslocando-a de uma mera narração factual do passado, e enlaçando os tempos, entre-tempos (DELEUZE; GUATTARI, 2005), em um passado-futuro-presente, em um processo de coexistência de tempos. Esses entre-tempos se referem não ao tempo linear e cronológico, mas aos tempos e fragmentos que nos orbitam, como as imagens do passado, que tendem por determinados movimentos encontrar brechas e irromperem no presente, o acontecimento entre um tempo morto, em devir. Este movimento nos traz composições singulares, pois toda repetição difere por seus outros sentidos sempre variantes, que se produzem nas relações entre sujeitos e nas contingências do encontro.

Assim, articulei esta história aos processos artísticos das apropriações, que possibilitam abordar a história da arte como uma potência, para problematizar nosso presente e nossas relações entre a docência e o currículo. Estas imagens relacionadas entre a história da arte e o presente, tornam-se escombros, sendo experienciadas durante a docência como campo de desorganização e desconstrução, dando espaço para outras invenções. Aproximei-me da leitura de Tomaz Tadeu da

\footnotetext{
${ }^{(*)}$ Carin Cristina Dahmer. Universidade Federal de Santa Maria. Programa de Pós-Graduação em Educação, Linha de Pesquisa LP4: Educação e Artes. E-mail: carindahmer@gmail.com.

Marilda Oliveira de Oliveira. Universidade Federal de Santa Maria. Professora Associada do Departamento de Metodologia do Ensino, Programa de Pós-Graduação em Educação, Linha de Pesquisa LP4: Educação e Artes. E-mail: marildaoliveira27@gmail.com.
} 
Silva (2004) para pensar um currículo de-formado, e de Deleuze e Guattari (2011) para articular as linhas de vida aos processos de apropriações.

Neste sentido, tomei a apropriação como conceito abordado por Archer (2012) para pensar a pós-modernidade e a arte, a partir do posicionamento pela não originalidade e autoria. E com Argan (2006) a partir dos primeiros movimentos do século XX, que propõe a incorporação de elementos às obras de arte. Este processo se estabelece pela multiplicidade, pois permite que inúmeras apropriações sejam realizadas por diferentes artistas, ou neste caso, por diferentes professores diante de seus currículos. As apropriações propõem a acumulação, incrustação de objetos heterogêneos, como as imagens e objetos do uso cotidiano, os deslocando e os desorganizando de seu habitual espaço, os movimentando a partir de invenções, experimentações, a fim de produzir sentidos singulares e outras composições.

Este processo me impulsionou a tensionar esta história da arte nos encontros com a educação. Diante deste processo de pesquisa me deparei no campo educativo com a dificuldade de produzir alguns desvios para o currículo escolar, no que diz respeito às artes visuais e a história da arte. A fim de traçar linhas, caminhos possíveis ao pensar-aprender sobre currículos que saltem por estes meandros, 'entre` de currículos para além do papel, permitindo em suas letras pequenas invenções, desdobramentos e potências no campo curricular. Neste sentido a problematização desta pesquisa perpassou estas questões: O que pode o currículo entre as apropriações e a história da arte e o que podem as apropriações para de-formar o currículo e a história da arte?

Para tanto, operei a pesquisa a partir da abordagem da cartografia de Deleuze e Guattari (2011), que apropriada por outros autores, tornou-se produtiva para o campo da educação. Neste sentido, não há procedimentos ou métodos que orientam a pesquisa em direção a um certo resultado. A pesquisa se delineou como uma experimentação, que foi sendo construída nesse processo, entre pesquisadora, corpos, vidas, encontros, desvios e paradas. Conforme coloca Oliveira (2014), articulando a cartografia aos territórios educacionais, relacionando as intensidades e desejos que movimentam o currículo e a história da arte, entre suas totalizações e fugas.

Na pesquisa cartográfica, não há percursos determinados, nem objetos e dados já sabidos $a$ priori para a pesquisa. O cartógrafo irá bordando este percurso, a partir dos encontros e desvios que acontecem nos territórios que são traçados, em meio a vida, sejam dos espaços educativos ou não, mas que se relacionem e movimentem a pesquisa.

Desse modo, a cartografia, propõe a destruição de alguns territórios, ou pelos menos algumas fissuras, erosões, e também sua reconstrução, a partir da criação de outros modos de 
operar, entre o currículo e a história da arte. O refazer-se com os escombros deste movimento, articula as apropriações como a incorporação de diferentes objetos e materiais para a criação de uma nova composição. Operando entre o currículo, a história da arte e a apropriação alguns desvios foram traçados, experimentando outros caminhos para os territórios educacionais e curriculares.

\section{ENTRE TERRITÓRIOS CURRICULARES, APROPRIAÇÕES E LINHAS DE VIDA...}

Um currículo é um conjunto de planejamentos, de conteúdos e avaliações, faz parte da organização escolar moderna, e do campo educativo contemporâneo; se apresenta normalmente compactado, como o conjunto das matérias de um curso escolar. Mas, pode ser também, como uma ação de correr, correr para fora, fazer vazar. Isso me interessa quando abordo o tema do currículo. Assim, esta pesquisa não procurou encontrar formatos (talvez, sim, des-formatar) ou definições absolutas sobre um currículo adequado. Já que, para explorar suas possibilidades no campo educacional, a decisão foi por produzir questionamentos e não buscar respostas ou soluções, como nos diria Silva (2002), mas, propor um professor problematizador que dance com seu currículo.

Para Lopes (2015) a própria significação do que deve ser entendido por currículo, está inserido em um debate que engloba concepções políticas, no que diz respeito às práticas de poder que envolvem sua definição. Os discursos como práticas de significação e de produção de sentidos vem aliados a uma determinada política de currículo, para que determinados planejamentos, conteúdos ou saberes oficiais prevaleçam sobre outros. Segundo Amorim (2012, p. 43) o currículo é construído a partir de sua nomeação, pelo seu caráter enunciativo, discursivo e pela sua significação, "Sua representação o falseia, julgam-no. Sua imagem é distorcida, condenam-no. Sua moral é desumana, aprisionam-no. Sua vida é transgressora, sonham-no. Seu nome é pedra, talhamno. Ao currículo nada pertence?” O currículo normalmente assume a sua constituição conforme o nomeiam, muitas vezes por simples simbiose, recogn7ição, mesmo não pertencendo aos sujeitos as definições que os contém. Propor que o currículo possa, a partir de diferentes singularidades se movimentar, em devir, pelas brechas dos planejamentos curriculares, foi o que problematizei nesta pesquisa.

A pesquisa curricular, segundo Corazza e Silva (2003), necessita adentrar em algumas forças e intensidades que percorrem os territórios curriculares, ao abordar a constituição do conhecimento e da verdade, como construções de sentido interpretativas, obtidas nos encontros entre forças, vontade de saber e vontade de poder. O currículo então, é uma construção política, na medida em que seus conhecimentos são selecionados, a partir de objetivos específicos, e de certa 
medida, contribui para a construção de subjetividades, ao mesmo tempo, em que também as produz. Propus que o currículo não se limitasse ao seu caráter representativo, dos valores, poderes, e aos conhecimentos intrincados neste processo, mas que diante deste currículo transbordamentos pudessem percorrer outros saberes. Foi através das apropriações da história da arte, um conhecimento hegemônico, que operei a construção de sentidos que problematizasse o presente, nas pequenas produções que se bordam nas fronteiras dos territórios curriculares.

A política curricular assume um papel importante para a educação, quando se consolida como detentora dos processos de significação, ao elencar os conhecimentos e formações válidas, como nos coloca Silva (2010). O currículo como prática cultural e de significação deve ser discutido, pensado, de-formado, desmontado, incorporado por apropriações através daqueles que o habitam, sendo movimentado a partir dos encontros e das suas contingências, entre currículos, estudantes, saberes, professores.

Mas, afinal, o que quer um currículo? É o questionamento que sugere Corazza (2001), carregado de fala-ação, de discursos, como uma linguagem, de práticas sociais e coletivas, quer representar a sociedade o qual está enredado, seus valores, saberes, poderes. Ao realizar uma pesquisa pelo pensamento do currículo, foco o olhar para os modos de discurso que operam através do currículo, não na busca por uma verdade, mas procurando produzir inusitadas construções de sentido no currículo, traçando brechas, transbordando singularidades e diferenças.

Para Rolnik (2006) o cartógrafo também tem um papel político, ao estar atento aos desejos, fluxos e intensidades do seu campo de pesquisa, assim, percebendo com os olhos e com o corpo vibrátil as relações entre estes movimentos. Afinal, este cenário se constitui pelo real social, pela vida que pulsa nos territórios que habitamos, e ao propor relações diversas com esses territórios, entre fugas e saltos, opera para que negociações aconteçam na sociedade que se está inserido.

Percebo que o currículo forma os sujeitos a partir de determinados enfoques, que, muitas vezes, acarretam no distanciamento de outros saberes. Segundo Lopes (2015), realizar a desconstrução de um currículo e de seus contextos nos permite a reativação de suas singularidades, em um movimento que remexe com os sedimentos do leito deste rio-currículo, seus fundamentos, seus planejamentos, a fim de que emerjam outras possibilidades.

São importantes estas problematizações, na medida em que articulo um currículo sem fundamentos, como nos coloca Lopes (2015), que se pretende muitos, não por um viés da universalidade, mas justamente percebendo em suas singularidades e experiências docentes, potências para construir outras relações entre conteúdos e os modos de pensar e aprender. Opero 
então, com as invenções possíveis deste currículo sem fundação, nos espaços de erosão do currículo adequado, construindo outras relações entre eles, com a criação de passagens, desvios.

Neste sentido, também trago de Silva (2004) a proposta de uma educação de-formadora, que visa a desorganização do organismo currículo, de seus conhecimentos e verdades. No sentido de não adentrar a padronização do pensar e aprender, mas a multiplicidade de modos de ser estudante, docente.

A constituição do currículo escolar pode se dar de diversas maneiras, o currículo no qual me debrucei, quando docente de uma escola de ensino fundamental, se compôs de muitas mãos. Cada professora de artes acrescentou nesse texto suas intenções, seus desejos, suas intensidades.

$\mathrm{Na}$ tabela dos saberes haviam, conceitos e conhecimentos, conteúdos conceituais; em fazeres, as habilidades, conteúdos procedimentais; em ser, as competências, conteúdos atitudinais; e em situações de aprendizagem, metodologias. Adentrar neste território da construção do currículo foi um processo potente. Estas palavras impressas como documento, como metas a serem cumpridas e avaliadas, territorializam o currículo, organizam os planejamentos escolares, tendem a enrijecer a dinâmica do pensar e aprender, ao compilar as trajetórias de aprendizado, construindo mapas-roteiros de percursos a serem seguidos. Estes planejamentos são importantes para o espaço escolar, mas sua constituição pode ter menos um saber adequado, e mais um saber negociado, cartografado, que compõe com as relações entre conhecimentos e desejos das diferentes contingências de cada encontro entre currículo, escola, estudantes e professores.

Assim, procurei bordar algumas experimentações entre as linhas do currículo fundamento/formatado/formado, e do currículo de-formado/sem fundamento/des-formatado que fui compondo, percebendo os percursos deste (rio)currículo nos territórios escolares. Afinal, Oliveira (2014) confirma que cartografar também é inventar palavras, decompô-las, para que possam tecer outras relações nesta escrita. O currículo rio de que aqui falo, propõe a criação em meio ao território curricular, ao traçado que se desfaz e produz outro caminho, para os desvios de um currículo igarapé, nas malhas de suas raízes. Nos tempos de cheia é aquele que se espalha entre os territórios, interrompe estradas, traça outros caminhos, adentra as casas, destrói plantações, revolve o leito do rio, carrega troncos de árvores, põe a mostra as raízes, constrói desvios, faz do rio percurso. Bordando entre palavras e conceitos, operando entre o documento que se cria em minhas mãos, um currículo de-formado.

O que pode o saber enquanto técnica? Ele pode ensinar, pode fazer memorizar: composição visual, desenhos geométricos, reutilização de materiais, efeitos de luz e sombra, cores, ponto e 
linha, pintura, proporções, simetria, colagens, escultura, perspectiva, volume, fotografia; arte préhistórica, arte egípcia, arte grega, arte romana, arte gótica, renascimento, barroco, neoclassicismo, romantismo, realismo, impressionismo, modernismo, expressionismo, cubismo, dadaísmo, surrealismo, pós-modernismo, arte contemporânea, arte conceitual, arte pop, etc., aqui compondo um território curricular da arte e da história da arte para todo um ensino fundamental. Posso problematizar este saber, bordar outras palavras neste currículo. O que pode o saber enquanto rio? O que pode o currículo enquanto rio? Que carrega a desorientação e também a vida, a destruição e a invenção, com outros platôs para adentrar, com outros caminhos para percorrer, saindo do leito, correnteza que incorpora e que compõe com o ensino, que produz entre memorizações, entre técnicas, algumas cheias.

Como adentrar a mata por estes igarapés escondidos da história da arte? O que pode a história da arte como sopro para a canoa deste currículo de-formado? O que pode dar vida a este passado, que tanto já se diz morto? A vida que pulsa, movimenta os desejos nos territórios curriculares, a vida de quem habita este currículo, como nos diz Silva (2002), pode dar impulso, salto, potência para a história da arte. Percebo que explorar essa temática perpassa a percepção de que a história pode se relacionar com o presente, operando para além de seu passado, através de uma perspectiva de coexistência destes tempos, a partir do que podemos produzir de sentidos contemporâneos com essas visualidades de outrora.

Ao abordar a fotografia, tanto sua construção, quanto seu feitio como câmera fotográfica pinhole ou como câmara escura de papelão, me detive por muitos entre-tempos em sua produção, imaginando que invenções poderíamos realizar no espaço da escola. Porém este planejamento não afetou os estudantes. $\mathrm{Na}$ realidade precisei abandonar este planejamento, para que outras linhas pudessem atravessar as aulas do nono ano. As tecnologias foram mais potentes e encontraram suas brechas, para que outra fotografia fosse possível, que lhes afetasse mais, com a câmera digital que já estava em suas mãos em seus dispositivos móveis.

Perceber que os planejamentos e os saberes que estão dispostos nos currículos, podem não facultar como dispositivo do aprender e pensar é importante para permitir como docentes, alguns desvios. Estes atravessamentos correspondem a estas brechas nos territórios curriculares, fissuras entre a organização e as intensidades de uma sala de aula. Para que os estudantes também ocupem este espaço do currículo, há de ter disponíveis muitas linhas e agulhas, para que o tecer deste pensar e aprender seja feito de muitas mãos. Não há um abandono desta linha da história da arte, mas trânsitos intensos entre o currículo e suas apropriações. Este movimento, às vezes, se torna difícil, 
mas alguns desvios destes planejamentos permitem que outros percursos sejam traçados, e talvez estes desvios se tornem mais produtivos em termos de experiência em arte e em educação.

Há muitas linhas que compõem os territórios curriculares. Há linhas de segmentaridade dura ou molar, linha de corte; linha de segmentação maleável ou molecular, linha de fenda, micropolítica; e linhas de fuga ou abstrata, linha de ruptura, a primeira, da qual as outras derivam. Os diferentes conjuntos de linhas que compõem os planos e territórios, coexistem, "mas também se transformam, passam uma nas outras" (DELEUZE; GUATTARI, 2012, p. 113), transitam entre linhas de vida.

A composição entre as linhas moleculares e as linhas de fuga, assumem alguns desvios, para o currículo e para a história da arte, ao propor pequenas resistências nos espaços entre as linhas duras. Assim, as linhas de fuga e as linhas moleculares percorrem os espaços do plano de organização em uma trama de coexistência dentro dos currículos e dos espaços escolares.

A composição entre linhas que percorrem o currículo, se constituem por inúmeros atravessamentos e trânsitos infinitos, linhas duras... linhas flexíveis... linhas de fuga... Estas conjunções ocorrem em determinados tempos e sujeitos, entre os singulares encontros dos corpos que habitam o currículo, por vezes atravessando linhas duras, negociando por linhas moleculares, ou se lançando em linhas de fuga. Entre árvores e rizomas, estas relações se emaranham como cama de gato, através deste trânsito que percorro durante a docência, dentro deste currículo que ocupo. Um movimento, devir-minoritário, ora clandestino, ora latente. Muitas são as linhas duras que transitam no currículo, sejam nos conteúdos ou nas docências enrijecidas, podemos tornar qualquer conteúdo da arte por linhas duras, se as relações entre sujeitos e os modos de estar docentes permanecerem estanques, sempre os mesmos.

Assim, as linhas duras do currículo, apresentam-se tanto pelos planejamentos e saberes que permaneceram como decalque, quanto pelo modo como nos relacionamos com estes saberes. Procuro então, problematizar a relação que estabeleço com o currículo, seja com a história da arte, seja pelos modos de estar docente. Propondo que, através das apropriações, possa então transitar entre estas diferentes linhas, entre os currículos e a história da arte.

Dentro do currículo decalque e dos conteúdos ali listados, foi possível articular alguns trânsitos em relação a história da arte, a partir do conteúdo, artistas viajantes do século XIX no Brasil. Esta linha dura tramada de forma rígida, parece em um primeiro momento como intransponível para um processo de pensar e aprender que se construa por signos, pelas brechas. Porém, ao trabalhar com a categoria das apropriações do currículo, opero nas brechas das linhas 
moleculares, incorporando elementos, desorganizando o currículo, no sentido de fazer alguns desvios por uma outra história da arte. A problemática deste tema se deteve primeiramente pelos espaços que os estudantes percorriam, na tentativa de percebê-los com o corpo vibrátil, a partir de diferentes ângulos e possibilidades, ao lançar seu olhar para o espaço da sala de aula.

Em um primeiro momento, o exercício de perceber os espaços da sala de aula, traçando linhas de desenho no caderno, posteriormente percorrendo outros espaços da escola, abordando-os como uma composição focada na construção de um olhar para os lugares que percorreriam cotidianamente. Para isso alguns questionamentos problematizaram este processo: Que outros olhares posso lançar para os espaços que ocupo e percorro? Que outros sentidos posso produzir a partir deste olhar e para este lugar?

Relacionar o processo passado, dos artistas viajantes do século XIX que percorreram o Brasil colonial para documentar a vida, se articulou ao processo que os estudantes do nono ano vivenciaram ao percorrer a escola, procurando perceber seus espaços, primeiramente pelo desenho e posteriormente pela fotografia. Esta foi uma tentativa de negociação, entre passado e presente, entre a história da arte contida no currículo e a problematização do cotidiano escolar. A questão aqui não foi fazer como os viajantes do século XIX, representá-los, imitá-los, e sim, colocar-se em diálogo com eles, aprender deles para produzir uma outra coisa. Uma linha de fuga deste conteúdo disciplinar, a fim de articulá-lo às apropriações, incorporando a história da arte, o olhar contemporâneo de quem a percebe hoje. Assim, aposto na de-formação destes saberes, por entre suas linhas, tramando outras possibilidades de problematizar o passado e também à docência em artes.

Acredito que inúmeras linhas tendem a tramar à docência, linhas segmentárias duras tendem a compor uma certa organização, um certo modo de estar docente, bem quisto e bem-vindo no espaço escolar, aquele docente que constrói seu currículo com inúmeros conteúdos, e este já está completo para todo o ano letivo, desde há anos.

Diferentes modos de estar docente ainda não são vistos como formas de multiplicidade e singularidade de cada docente. Há linhas que tendem em querer impor caminhos, e que não estão aptas ao diálogo entre diferentes, suas tramas já estão acostumadas e não desejam fazer saltos. Mas se há tramas que teimam em dizer que há inúmeros tons de azul no mar, estamos construindo pequenas rupturas. Se há tramas que negam a representação como única opção para o pensar e o aprender, então surgem pequenas resistências. Se há tramas que permitem o currículo de-formado, então há pequenas apropriações. 
Bordar entre currículos e a história da arte me fez buscar uma boa agulha, afiada a ponto de perfurar os tecidos mais rígidos e que possa, vez ou outra, perder seu olho, nomeada aqui, apropriações. Para tecer essas composições curriculares a linha se fez necessária, mas uma linha que possa ser rompida, que se desfaça em fiapos permitindo caminhos inúmeros, que se faça muitas, essa sim serão as linhas de vida.

O conceito de apropriação, tece e costura a pesquisa, como uma categoria que opera o currículo, como um processo de invenção, de seus bordados e colagens alinhavados pela história da arte. Assim, me aproximo desse conceito, primeiramente através dos movimentos artísticos do século XX. Segundo Argan (2006) é possível perceber que nesse período de transição dos movimentos artísticos, em que a representação não é mais o foco de suas produções, há a ampliação do escopo dos processos e técnicas que envolveram seu feitio. A estruturação da obra de arte se baseia não mais na representação, mas sim na forma, na união entre objeto e espaço. É com o Cubismo, através de Picasso e Braque, que teremos os primeiros ensaios desse procedimento da apropriação, onde a forma passa a sobressair pela tela, com a utilização de materiais e técnicas não usuais para a arte. Esses materiais considerados refugos, ou que pertenciam ao uso cotidiano, agora adentram ao espaço da arte. Para isso a colagem de cartas, tecidos, caracteres tipográficos, recortes variados, areia, reboco, etc.; uma grande variedade de objetos e imagens, passam a fazer parte do campo da criação da obra de arte. A apropriação como procedimento artístico, se baseia na seleção de objetos e imagens, de obras de arte ou não, que passam a compor entre si uma outra obra.

As inúmeras apropriações possíveis propostas pelo Cubismo, também permearam outros movimentos artísticos, como o Dadaísmo, principalmente com Duchamp, o Surrealismo e Arte Pop, assim como a música, o teatro e a literatura. Para Argan (2006), Duchamp exerceu uma ruptura mais extrema, ao elencar os objetos de uso cotidiano como detentores de valor estético, como obra de arte, ao serem autorizados pelo artista, através da assinatura, a ocupar os espaços legitimados da arte, como museus, galerias e exposições.

Realizar a articulação entre o que as apropriações propõem e operar com essa categoria no campo da educação, perpassa a percepção de que as engrenagens desse procedimento possibilitam trabalhar justapondo os currículos, o qual incrustamos de outros objetos e imagens, conceitos e conteúdos, a fim de criar outros sentidos para o que vemos e convivemos, seja para a arte, seja para a educação.

As diferentes apropriações que saltitam no campo da arte, exercem potência para que no decorrer da docência, variados elementos se incorporem ao currículo, o bordem, o operem. $\mathrm{O}$ ato de 
selecionar estes objetos e imagens para compor uma obra ou um currículo, perpassam todo o percurso que me (de)forma. Foi através das andanças, das conversas, que fui selecionando aquilo que me salta aos olhos, que cintila. Entre todos os refugos, recolho e guardo os elementos que vibram nos olhos e no corpo. São talvez lembranças recolhidas ao acaso, ou que se enlaçam em inúmeras memórias, estas inventadas ao toque dos dedos. Coleções muitas que compõem a vida que tenho experienciado. São livros antigos em alemão, que não sei ler, são passagens de ônibus, trem, metrô, ingressos, folhetos, cupons fiscais, e muitos cadernos, de variados tamanhos, escritos ou não, ganhados ou roubados. Estes objetos testemunham uma vida, e por um breve momento se encontraram com a minha, para compor outros sentidos, serem tecidos, bordados entre o que se cria, por um currículo e outro, entre apropriações e histórias. Ao abordar a obra de Schwitters, Argan nos coloca.

Na docência, na existência, recolho escutas, muitas.. recolho gestos, desejos, intensidades.. adentro o currículo, sobrepondo as experiências, entre o que dizem por aí que o currículo quer, entre o que os estudantes desviam diante da história da arte. Acolher vontades, negociar saberes, cortar as margens de um currículo, para acrescentar palavras, imagens, composições.

Que outra vida, pode ter um quadro de Leonardo da Vinci? Perambulando entre o currículo decalque, entre a história da arte e o renascimento, há linhas que se desfazem, fiapos que vagueiam em direções inesperadas, movimentos entre a perspectiva e a colagem, incorporação de materiais para a sua construção, o desenho do impossível, e a obra de Escher. Que outras de-formações na história da arte posso sobrepor pelas apropriações de um currículo?

Apropriações, bordados pelas imagens do passado, linhas que tecem relações entre o passado e o presente, sobreposição de tempos. Para isso, opero estas imagens como lâminas sobrepostas de temporalidades diferentes, que compõem outra imagem, da maneira como faz o artista paulistano Albano Afonso. $\mathrm{O}$ artista realiza experimentações com as obras de alguns mestres da pintura, como El Greco, Goya, Rubens, Velásquez, Rembrandt, entre outros. Seu trabalho consiste em perfurar repetidamente as reproduções em fotografias das pinturas com círculos vazados pela superfície da obra, revelando assim partes de outra imagem posta em um segundo plano. Essa sobreposição possibilita rever o instituído de um ângulo diferente, pois impõe fraturas e a travessia de outros elementos, produzindo inusitadas composições, ou apropriações diante de uma imagem da história da arte.

Segundo Cherem (2009) as imagens do passado afetam o presente quando atuam como vibrações. Nas obras produzidas por Afonso, o passado é justaposto ao presente articulando estes 
tempos que passam a coexistir fisicamente nestas aberturas. Sua potência para produzir outros sentidos no presente se encontra nestas rupturas, lapsos, entre esquecimentos e recolhas, nas suas fissuras. Ao abordar a história da arte, percebo o que se incrusta, incorpora nesta imagem que se compõe, "vestígios e sintomas partilhados" (CHEREM, 2009, p. 136), persistências e cintilâncias.

São estes aspectos que problematizam as imagens em seu presente, sem se fixar unicamente no passado, procurando perceber os 'sintomas' que as imagens portam e sua potência para problematizarmos sobre a contemporaneidade.

As apropriações assumem um caráter de invenção a partir de inúmeros elementos heterogêneos recolhidos do mundo da existência, da vida. Assim como da própria existência de quem cria, artista professora, que diante do currículo escolar, alinhava a história da arte atravessada de bordados, justapondo, acumulando o passado dessas imagens, as percepções que tramamos com elas. A história da arte narrada nestas linhas, diz respeito a história da arte ocidental hegemônica, dos movimentos artísticos que encontramos nos livros. Porém, a olhamos através de lentes que incrustem outras relações em seus quadros, esculturas, gravuras. Realizei a experimentação de perceber a história da arte operada pelas apropriações, pela incorporação de elementos que produzam nessas imagens outros sentidos.

Para Archer (2012) há diversas abordagens para a história da arte, uma delas abala a percepção de uma progressiva construção de seu conhecimento. Durante a pós-modernidade, segundo Silva (2015), as grandes narrativas da história e da história da arte, são relacionadas a potência das singularidades, e não mais a um domínio totalizador.

Assim, também a arte, não é mais exigida a ser contada através de uma construção progressiva, da criação do 'melhor` conteúdo, em relação a épocas anteriores. Já que, "tudo já havia sido feito; o que nos restava era juntar fragmentos, combiná-los e recombiná-los de maneiras significativas" (ARCHER, 2012, p. 156). A liberdade da arte contemporânea para os processos artísticos, perpassa as apropriações como invenção a partir de diferentes materiais e técnicas, trabalhando com o refugo e sua incorporação na arte. As apropriações são operações que incorporam variados elementos a obra de arte, acumulam, justapõem, incrustam, o mundo real e a arte, objetos e imagens variados, experimentações que nos anos oitenta são evidenciadas na arte com mais ênfase.

Ao operar um currículo que se costure entre apropriações, que ora incruste e ora se desfaça, invento um movimento para seus conteúdos e planejamentos, que desorganize suas estruturas, que incorpore a história da arte e tantos outros elementos que compõem uma aula de artes, através da 
existência/recolha de cada estudante. O movimento de recolha perpassa tanto as apropriações, quanto o currículo, que também seleciona os conhecimentos que nele se incrustam. Proponho então pensar sobre os significados dessas incorporações e suas relações entre as imagens do passado e as imagens e objetos associados hoje a estes currículos, fazendo com que a apropriação movimente a história da arte e o currículo, para que seja construída algumas (de)formações em suas estruturas.

Com o currículo formatado para os componentes do planejamento escolar, adentrei por um pequeno desvio, no que diz respeito a própria organização dos conteúdos. Da organização linear e cronológica, propus que tomássemos um caminho a partir da construção de projetos de pesquisa, em uma turma, a escolha se deu pelo tema da arte e natureza. Construir estas negociações entre o currículo e os estudantes, produz um potente movimento pelos conteúdos estáticos dos territórios curriculares. Aproximando assim, a história da arte contemporânea através da land art (arte da terra), foi se delineando linhas em fiapos para inverter a ordem dos planejamentos, a partir do que vibrava nos corpos dos estudantes. As experimentações articularam a percepção da natureza que os estudantes vivenciavam cotidianamente, e a possibilidade de vê-la como potente para a construção da produção artística. Um material que se apresentava como um refugo, era desdobrado por apropriações pelos estudantes.

Perceber a paisagem como meio, caminho para produzir outros sentidos. A terra vai sendo bordada por seus territórios naturais, subjetivos, criando experimentações nos espaços para fora do papel. Percorrer a escola, recolher materiais, selecionar, transitar pelos territórios curriculares, construir memórias, propor intervenções. Há muitos fiapos a percorrer, problematizar a relação da arte com o espaço, com o meio ambiente, com o espectador, com o tempo. Intervir no espaço da escola com suas experimentações deslocou o trabalho isolado da sala de aula para a presença de todo um público, da produção a partir de suas percepções, desejos. Paisagens naturais, paisagens culturais, percorrer e perceber as sutilezas de cada território, construção de mapas, significados, pequenos recortes, recolhas da memória, de-significar, abrir caminho. Assim, a composição deste conteúdo foi tramado a partir de vários elementos: com as imagens dos artistas (a)bordados, da land art, intervenções, territórios, de colagens, de linhas, sobrepondo, excluindo, incorporando outros heterogêneos, para a construção de uma composição carregada de sentidos singulares, entre o encontro de cada estudante, sua existência, as imagens, a comunidade escolar e o currículo.

Essa experimentação propôs que pelo viés da arte contemporânea algumas composições fossem tramadas, entre a história da arte e seus artistas, entre o território do currículo, deslocado de sua estrutura linear e cronológica, articulando algumas apropriações a organização escolar. Não há percursos adequados a serem seguidos, há apenas experimentações entre currículo e história da arte, 
que aqui são operados pelas apropriações. São desvios, aberturas, cheias, de-formações que tenho bordado na docência que experiencio.

O currículo formador se atem, segundo Silva (2015), principalmente a organização escolar (o que ensinar) e ao método (avaliação), que apesar de ser uma concepção moderna, ainda perpassa a espaço escolar contemporâneo. O território do currículo necessita ser de-formado, para que outras possibilidades se apresentem neste campo, alguns desvios e tensões, negociações em épocas de cheias evidenciam a vida, as relações entre documento, papel, letras, e apropriações, desejos, linhas.

Para operar o bordado entre o currículo e a história da arte, as apropriações incorporam elementos do presente neste passado e nesta organização, compondo outros percursos e confundindo fronteiras entre o currículo-rio e a coexistência de tempos. Algumas negociações nesse território revolveram raízes.

\section{ALGUMAS LINHAS AINDA SOLTAS.}

Ao (a)bordar as apropriações do currículo como possibilidade de de-formação dos planejamentos, componentes que delimitam e enrijecem a organização escolar, articulei alguns conceitos para tecer 'entre' as linhas da vida e a cartografia, uma aproximação com Deleuze e Guattari. Propondo a invenção de currículos de-formados, ao estabelecer uma conversa com Silva. Este movimento na pesquisa nasceu dos encontros que tive durante a existência, das potências que se inflamaram, procurando problematizar a vida e o modo como com ela me relaciono, pelos igarapés da história da arte, adentrando desvios, para assim percorrer outros caminhos educativos. Segundo Fonseca (2006) a pesquisa irrompe de maneira repentina, como magma, que em estado latente esteve à espreita de encontros.

[...] trata-se de nos encontrarmos com as vertigens do devir sempre ventando, para que possamos manter o chamado ao presente e a porosidade necessária para entender o ato de pesquisar como um trampolim para a vida. (FONSECA et. al. , 2006, p. 657).

As apropriações potencializam o currículo, ao atravessar rios, procurando uma terceira margem, que está sempre em deslocamento. Leva-nos a remexermos no leito destes rios, revirarmos as raízes em busca de rizomas. Propor apropriações para o currículo, diz respeito a todas as multiplicidades possíveis dentro desses rios, diz respeito a redemoinhos, a correntezas inesperadas e sem percursos pré-determinados. Alguns currículos-rio maquinados para fazer vazar, por igarapés, por várzeas infinitas, e não por verdades absolutas, ou por respostas adequadas. Entre linhas, procurar saltar, dançar, como cama de gato, sempre em movimento e com possíveis recombinações. 
Esta pesquisa se fez por redemoinhos e não trouxe respostas prontas, pois estas são linhas em fuga. As linhas que propus são as que não sabemos de onde vem e nem para onde vão, porém, seu meio nos entrecorta, nesse movimento produz-se relações múltiplas, entre currículos e apropriações, que serão sempre outras, pelas diferentes linhas que tramam à docência do devir. Mas há cortes que algumas linhas fazem, e saltos por entre territórios, de-formando currículos, planejamentos, linhas e docências. Esta pesquisa assim se fez, entre linhas de uma docência, entre linhas desta escrita, e entre linhas de quem a lê, os 'nós`, os saltos cabem a você leitor, pois eu já não tenho mais autoria sobre os roubos que lhe convém.

Adentrar um território curricular, operando as apropriações como linhas que tecem esse bordado, aproximando a história da arte do presente, focando o olhar e o corpo vibrátil para as relações que acontecem nesses encontros, entre currículo, estudantes e docente, que linhas de fuga foram traçadas, que linhas duras permaneceram, que cartografia destes corpos foram produzidas e o que delas me afetaram. Este processo se fez durante inúmeras aulas, e sob o olhar atento de quem está à espreita destes encontros, dos que me serviram, das tramas que se sobrepuseram e também das que fugiram.

Assim, nesta pesquisa procurei problematizar as possíveis articulações entre o currículo escolar e as apropriações como invenção, potência educativa para a docência em artes visuais. As experiências como docente e as leituras e contextos que me produzem diariamente são espaços das diferentes tramas da docência, linhas que reconstroem por um currículo, por apropriações, por resistências e por deslocamentos. A partir das possíveis brechas produzidas pelas apropriações da história da arte, procurei perceber os caminhos, resultados que foram traçados durante a docência, sua cartografia, processos que mobilizam à docência e mobilizam os estudantes envolvidos neste percurso.

Propus um diálogo entre o currículo, a apropriação, a arte e a educação, assuntos potentes que perpassam a escola e a trama da docência. $\mathrm{O}$ currículo tende a se apresentar como documento oficial, que contém as verdades, os conhecimentos, que perpassam a escola e toda a trama de docências. Pensar a partir das relações que se estabelecem por estes sujeitos que movimentam o currículo cotidianamente, é uma pauta importante para a docência, que se faz a cada experiência vivida.

Estas são apenas escritas em desvio, em fuga, que procuram perceber a cartografia destas tramas que envolvem a docência, para inventar outras. O currículo perpassa as relações possíveis entre estudantes, docentes e suas de-formações, possibilitam diferentes percursos para o campo 
curricular. Estas foram algumas linhas soltas, que por estes percursos como docente me vi atravessada. Procurando caminhos, desvios e atalhos para propor apropriações 'entre` a história da arte, para bordar algumas linhas de fuga no currículo escolar, atravessar algumas linhas moleculares, entre desvios, passagens e coexistência, um percurso na docência em artes visuais.

\section{REFERÊNCIAS}

AMORIM, A. C. Deleuze e Currículo no intervalo de palavras e imagens. In: FERRAÇO, C.E.; GABRIEL, C.T.; AMORIM, A.C. (Orgs). Teóricos e o campo do currículo. Campinas: SP: FE/Unicamp, 2012. p. 43-55.

ARCHER, M. Arte Contemporânea: uma história concisa. 2. ed. São Paulo: Editora WMF Martins Fontes, 2012. 263p.

ARGAN, G. C. Arte moderna. Trad.: Denise Bottmann; Federico Carotti. 2. ed. São Paulo: Cia das Letras: 2006. 709p. CHEREM, R.M. Imagem - acontecimento. In: Linhas cruzadas: artes visuais em debate. SILVA, M.C.R.; MAKOWIECKY, S. (Orgs.). Florianópolis: Ed. UDESC, 2009. p. 131-156.

CORAZZA, S. O que quer um currículo? pesquisas pós-críticas em Educação. Petrópolis, RJ: Vozes, 2001. 150p.

; SILVA, T. T. Composições. Belo Horizonte: Autêntica, 2003, 132p.

DELEUZE, G.; GUATTARI, F. O que é a filosofia? Trad.: Bento Prado Jr.; Alberto Alonso Muñoz. Rio de Janeiro: Ed. 34, 2005. 271p.

; GUATTARI, F. Mil platôs: capitalismo e esquizofrenia. Trad.: Ana Lucia de Oliveira, Aurelio Guerra Neto; Celia Pinto Costa. São Paulo: Editora 34, 2011. 127p. vol. 1

; GUATTARI, F. Mil platôs: capitalismo e esquizofrenia. Trad. Aurélio Guerra Neto, Ana Lucia de Oliveira, Lucia Claudia Leão; Suely Rolnik. São Paulo: Editora 34, 2012. 141p. vol. 3.

FONSECA, T. et. al. Pesquisa e acontecimento: o toque no impensado. Psicologia em Estudo, Maringá, v. 11, n. 3, p. 655-660, set./dez. 2006. Disp.: 〈http://www.scielo.br/pdf/pe/v11n3/v11n3a21.pdf $>$. Acesso em: 5 nov. 2014.

LOPES, A. C. Por um currículo sem fundamento. In: Linhas Críticas, Brasília, DF, v. 21, n. 45, p. 445-466, mai./ago. 2015. Disp.: 〈http://periodicos.unb.br/index.php/linhascriticas/article/view/16735/11881〉. Aceso em: 10 abr. 2016.

OLIVEIRA, T.R.M. Mapas, dança, desenhos: a cartografia como método de pesquisa em Educação. In: MEYER, E.D.; PARAÍSO, M. (Orgs.). Metodologias da pesquisa pós-críticas em educação. Belo Horizonte: Mazza Edições, 2014. p. 281-305.

ROLNIK, S. Cartografia sentimental: transformações contemporâneas do desejo. Porto Alegre: Sulina; Editora da UFGRS, 2006. 248p.

SILVA, T.T. A arte do encontro e da composição: Spinoza + Currículo + Deleuze. Educação \& realidade, Porto Alegre, Universidade Federal do Rio Grande do Sul, v. 27, n. 2, p. 47-57, jul./dez. 2002. Disp.: http://seer.ufrgs.br /index.php/educacaoerealidade/article/view/25915/15184. Acesso em: 23 mai. 2016.

\footnotetext{
. A filosofia de Deleuze e o currículo. Goiânia: Faculdade de Artes Visuais, 2004. 87p. $117 \mathrm{p}$.

O currículo como fetiche: a poética e a política do texto curricular. Belo Horizonte: Autêntica Editora, 2010.
} 2015. 154p.

Documentos de identidade: uma introdução às teorias do currículo. 3. ed. Belo Horizonte: Autêntica Editora,

Revista Teias v. 18, n. 50, 2017 (Jul./Set.): Conversas sobre formação de professores, práticas e currículos 


\section{RESUMO}

Este artigo aborda os territórios curriculares a partir de um currículo escolar experienciado nas aulas de artes do ensino fundamental ao articular a temática da história da arte. Considera os planejamentos escolares a partir das relações entre os conceitos: apropriação, Archer (2012) e Argan (2006); linhas de vida de Deleuze e Guattari (2012). Objetivou-se potencializar o currículo pelo viés da de-formação (SILVA, 2004), no que tange aos seus possíveis desvios. A metodologia adotada foi a cartografia como forma de perceber os percursos de uma docência em vias de se fazer. Assim, percebeu-se como resultado as potencialidades da composição de um currículo, a partir de algumas brechas, concluindo como percurso possível o entrelaçamento da história da arte a um tempo presente.

Palavras-chave: docência, currículo e apropriações.

\section{APPROPRIATION IN CURRICULAR TERRITORIES: CARTOGRAPHING DE-FORMATION IN HISTORY OF ART ABSTRACT}

This article approaches the curricular territories as from an school curriculum experienced at classroom in classes of art of an elementary school articulating it with the history of art thematic. It ponders the planning of the school curriculum from the relationship between the concepts: appropriation, Archer (2012) e Argan (2006); lines of life of Delouse and Guattari (2012). The aim was to potentialize the curriculum through the bias of un-formation (SILVA, 2004), in regards of its possible deviation. The methodology adopted was the cartography as a form of perceiving the routes of a teaching construction. Therefore, it was noted as a result of the potentials of the compositions of the curriculum, through some breaches, concluding as a possible path the interlacing of history and present time.

Keywords: teaching, curriculum, appropriation.

\section{APROPIACIONES EN LOS TERRITORIOS CURRICULARES: CARTOGRAFANDO DE-FORMACIONES EN LA HISTORIA DEL ARTE RESUMEN}

Este artículo aborda los territorios curriculares desde un plan de estudios experienciado en las clases de la enseñanza primaria al articular la temática de la historia del arte. Considera los planes escolares desde las relaciones entre los conceptos: apropiación, Archer (2012) y Argan (2006); líneas de vida de Deleuze y Guattari (2012). Se planteó potencializar el plan de estudios por la mirada de la deformación (SILVA, 2004), en lo que respecta a sus posibles desviaciones. La metodología adoptada fue la cartografía como forma de darse cuenta de los percursos de una enseñanza en vías de se hacer. Así, se contempla como resultado la potencialidad de la composición de un plan de estudios desde algunas grietas, entretejido de a historia del arte a un tiempo presente.

Palavras-chave: enseñanza, plan de estudios, apropiaciones.

Submetido em Nov./2016

Aceito em Jul./ 2017

Revista Teias v. 18, n. 50, 2017 (Jul./Set.): Conversas sobre formação de professores, práticas e currículos 